\title{
Sector Sarajevo (2013)
}

Documentary film, colour, 66 min.

Directed, written and narrated by BARRY STEVENS.

Cast: Lewis MacKenzie, Scott J. Casey, Greg Alkerton, Martin Bell.

Canada: 52 Media Inc.

Language: English

Every year since 1931 on 11 November Canadians celebrate Remembrance Day, a holiday that commemorates the men and women who served and continue to serve in the armed forces during war. Last year as part of the commemorations, History Television, a thematic channel subsidiary of the media corporation Shaw, aired a documentary recounting the Canadian forces' involvement in the Bosnian War in 1992. The aim of the documentary is straightforward and resonates with the celebration it was chosen to commemorate. If the people in Canada 'have no concept of what took place there' (as claimed by one of the interviewed soldiers), then the intention behind Sector Sarajevo is to make them aware of their bravest fellow countrymen, involved in what was 'the longest siege in modern history'. Similarly straightforward is the narrative twist that the documentary pivots upon: the Canadian regiment, guided by General Lewis MacKenzie, entered Sarajevo on 2 July 1992 on a peacekeeping mission but, due to extreme circumstances, they eventually had to renounce the UN's Chapter Six resolution, which stipulates that peacekeepers should not use force unless under direct attack.

Despite its commemorative mandate, Sector Sarajevo avoids dwelling upon the emotional realm. The impact of the events of July 1992 on the lives of some of the Canadians involved is addressed ${ }^{1}$, but appropriately this remains peripheral to the piece. However, director Barry Stevens spares us an expected happy-end manoeuvre. Instead, the brutal events of 11 July, when snipers shot children approaching the United Nations for candy, are brought into question. Some of the Canadians allege that this was actually Bosnian Muslims firing at their own people, in an effort to stir the international community to take a position against the Army of Republika Srpska.

The greatest merit of Sector Sarajevo is that, while revisiting the traumatic war zone experiences and paying tribute to the Canadian involvement in the siege, it does more than simply sympathize with MacKenzie's regiment. By looking at the way the Canadian peacekeepers who were distributing food and medical supplies under fire, but ended up being treated as enemies by both sides of the conflict, the documentary questions the effectiveness of the United Nations policies in scenarios such as Sarajevo. The finale of the piece is dedicated to the question 'Was it worth it?' - a question that each soldier and survivor answers in a different way.

\footnotetext{
${ }^{1}$ For example, Corporal Greg Alkerton turned to self-medication to overcome post-traumatic stress, while others took their own lives.

(C) School of Slavonic and East European Studies, University College London, 2014.
} 
A final remark should be made about the self-reflexive aspect of the documentary. The date 13 July marked the greatest crisis in the Canadian involvement in Sarajevo. On that day, the Bosnian militia had surrounded Canadian tanks, which had been ordered to the outskirts of the city to distribute provisions. With rifles pointed at them, accused of smuggling weapons to the enemy, the Canadians were asked to surrender their weapons and either give up their armoured tanks or stand their ground and die. The United Nations headquarters did not supply MacKenzie with any helpful advice on how to proceed (he claims that the person who picked up the line in New York did not even know where Sarajevo was). However, he ultimately resolved the crisis by acquiring footage of the ongoing standoff from the BBC correspondent Martin Bell and showing Bosnian President, Alija Izatbegović, how the incident would be portrayed in the media.

This crucial final aspect becomes a great testimony to the positive ethical power documentary filmmaking and news reporting can, at times, exercise over the modern world. In this respect, Sector Sarajevo is as inspiring as it is disturbing, given its subject matter.

GIACOMO BOITANI

Independent Scholar

This work is licensed under the Creative Commons Attribution-Non-commercial-Share-alike 2.0 UK: England \& Wales License. This license allows for redistribution and alteration, commercial and non-commercial, as long as credit is given to the author. To view a full copy of this license, visit: http://creativecommons.org/licenses/ or send a letter to Creative Commons, 444 Castro Street, Suite 900, Mountain View.

(C) School of Slavonic and East European Studies, University College London, 2014. 